\title{
HUMAN RESOURCES PRACTITIONERS' PERCEPTIONS OF THEIR ROLE AND RESPONSIBILITY IN MANAGING HIV/AIDS IN INDUSTRY
}

\author{
C DE W VAN WYK \\ WorkWell: Research Unit for People, Policy and Performance, \\ School of Behavioural Sciences, \\ North-West University (Vaal Triangle Campus) Vanderbijlpark
}

\begin{abstract}
The central question to be examined revolved around an analysis of the perceptions of Human Resources Practitioners regarding their role and responsibility in the management of HIV/AIDS in industry. A convenience sample of HR Practitioners was used in a cross-sectional design. A questionnaire measuring the constructs of managing HIV/AIDS in industry, as well as a biographical questionnaire was administered. The questionnaire proved to be reliable. A Cronbach alpha coefficient of 0,82 and 0,71 was obtained. Descriptive statistics were used to analyse the data. Results indicated that HR Practitioners experienced and perceived significant differences with regard to the implementation of their companies' policy formation and -implementation, training needs of managers and employees, mentoring/ coaching -approaches and other AIDS-related issues in terms of their perceptions regarding the management of HIV/AIDS.

The findings revealed a gap of knowledge on managing HIV/AIDS existing among HR Practitioners at all levels. While some HR Practitioners had a detailed knowledge of the disease and its prevention, others were ignorant about it, but agreed that the management of HIV/AIDS can be seen as an integral part of their daily role and responsibility in industry. Recommendations were proposed for future research, policy making and practice in the area of HIV/AIDS and the management thereof.
\end{abstract}

Key words

HIV/AIDS, perceptions, HR Managers, role and responsibility, management of HIV/AIDS

HIV, or human immunodeficiency virus, is an organism that infects and kills white blood cells that play a crucial role in fighting off disease. HIV is a delicate virus that dies if it is exposed to air. It cannot be transmitted by casual contact as is the case with cold and influenza viruses. Known methods of transmitting HIV include incidental or deliberate mixing of infected body fluids, unprotected sexual intercourse (both heterosexual and male homosexual), transmission through infected blood during transfusions, sharing of contaminated needles among illegal intravenous drug users, accidental "needle pricks" or other exposure to blood products of infected patients (such as contact of infected blood with eyes or mucous membranes or with a cut or lesion on the skin) among health care workers, and prenatal transmission from mother to foetus (Firmansyah \& Kleiner, 1999). HIV/AIDS has reached epidemic proportions in South Africa and has serious consequences for individuals as well as for South Africa's health resources and the economy. The negative impact of HIV/AIDS may adversely affect efforts directed at addressing structural problems, including high levels of unemployment, the skills shortage and high levels of income inequality.

There are different theories that can be applied when testing people's perceptions, for instance the ecological theory, the attitude theory and the attribution theory. For this research, it has been decided to use the attribution theory. Attribution theory is seen as very relevant to the study of a person's perceptions, event perceptions and attitude change, which can then lead to individuals impacting their own self-esteem, as well as their own levels of anxiety. Examples of self-attribution theory include situations which may be positive or negative. The attribution theory describes also how people judge others. They see behaviour, judge the behaviour in terms of intention of purpose, and then draw a conclusion, which in essence is an attributed disposition. Inaccurate or not, this is a common human behaviour that transcends many social interactions (Heider, 1944; Jones \& Davis, 1965; Kelley, 1967).

"In psychology and the cognitive sciences, perception is the process of inquiring, interpreting, selecting, and organising sensory information. Methods of studying perception range from essentially biological or physiological approaches, through psychological approaches to the often abstract 'thought-experiments' of mental philosophy". (Wikipedia, 2006).

The aim of this study was to assess the HR Practitioners' perceptions regarding their role and responsibility in the management of HIV/AIDS in industry. For this research, a quantitative design was used and a total of $65 \mathrm{HR}$ Practitioners (from HR Officer to HR Manager) responded by completing a semi-standarised questionnaire as well as a biographical questionnaire.

Two decades have passed since the onset of the epidemic that arose from the acquired immune deficiency syndrome, otherwise known as AIDS. The literature on AIDS is extensive, yet relatively little attention has been devoted to testing the perceptions of the different role players, and more specifically the youth on this disease. AIDS has killed more than 25 million people since it was first recognised in 1981, making it of one of the most destructive epidemics in recorded history. Despite recent, improved access to antiretroviral treatment and care in many regions of the world, the AIDS epidemic claimed 3,1 million [2,8-3,6 million] lives in 2005; with more than half a million (570 000) thereof being children. The total number of people living HIV has reached its highest level: an estimated 40,3 million [36,7-45.3 million] people are now living with HIV. Close to 5 million people were newly infected with the virus in 2005 (UNAIDS \& WHO, 2005). More than 90 per cent of all adult HIV infections occurred in developing countries and two-thirds were infected in Sub-Saharan Africa. The South 
African population was expected to grow from 43,7 million in 1999 to 51,3 million in 2010 in the absence of HIV/AIDS. However, because of the incidence of HIV/AIDS, the population is now expected to reach only 47 million in 2010 (Kaiser Family Foundation, 2000).

Southern Africa remains the epicentre of the global AIDS epidemic. New data from South Africa shows HIV prevalence among pregnant woman has reached its highest levels to date: $29,5 \%$ [range 28,5-30,5\%] of woman attending antenatal clinics were HIV-positive in 2004. Prevalence was the highest among woman aged 25-34 years - more than one in three women was estimated to be living with HIV. Among woman aged 20-24 years, almost one in three was infected. In the country's worst affected province, KwaZulu-Natal, prevalence has reached $40 \%$, while it remained exceptionally high at between 27\% and 31\% in the Eastern Cape, Free State, Gauteng, Mpumalanga and North West provinces. (Department of Health, South Africa 2005).

It is estimated that the HIV-positive population in 2004 was approximately 3,83 million, which translates to an HIVprevalence rate of $15,2 \%$ of the adult population. The accumulated AIDS deaths up to 2004 were estimated to be 1.94 million (Statistics South Africa, 2004). Abt Associates (2000) project that by 2010 the labour force will, in the absence of substitution, decline by 8 per cent for the highly skilled, 10 per cent for the skilled and 11-13 per cent for the semi- and unskilled.

Quattek (2000) predicted an average decline of $10 \%$ in the labour force over the period 2000-2015, spread across all skills levels. As a result of this it may be difficult to maintain and increase the pool of sufficiently skilled people needed to match the skills demand as well as the expected economic growth. Vass (2002) reported that this situation might not ease, as HIV/AIDS was likely to exacerbate the current short supply of skilled labour in the absence of sufficient replacements and retraining. According to Van Aardt (1999) about 21\% of South Africa's workforce would be infected by 2010 and about $3 \%$ will have had full-blown AIDS. In the same period, the number of employees lost to AIDS could amount to around $40 \%$ to $50 \%$ of the current workforce in some South African companies (Kaiser Family Foundation, 2000).

The epidemic also affects many people's life expectancy at birth. During the period 1996-1999, the life expectancy in the era of AIDS in South Africa declined from 63 to 55 years. In neighbouring countries also hard hit by the disease, namely Botswana and Zimbabwe, life expectancy dropped from 65 to 47 years and from 53 to 44 years respectively (Sunter \& Whiteside, 2000).

The BER (2006 p.9) reported: "The balance of evidence in South Africa indicates that lower skilled (and income) people tend to have higher prevalence than the higher skilled (and better paid). This does not reflect racial factors only. According to Dorrington (2002) the existing information shows a particular steep downward gradient in infection levels as we move from the semi-skilled job categories to middle and senior management level amongst blacks; in fact, it appears that HIV prevalence could be independent of race at senior management levels.

Table 1 indicated that a significant increase in the number of HIV-positive people in the various stages of the HIV/AIDS lifecycle, particularly the later stages, could be expected during the period 2002 to 2008. It also appeared from Table 1 that the number of South Africans in the early stages of the HIV/AIDS lifecycle would show only limited increase from about 1,8 million in 2002 to about 2,1 million in 2008 ( $17 \%$ growth rate). However, a far stronger increase $(28 \%)$ is anticipated in the middle stages, namely from about
2,5 million in 2002 to about 3,1 million in 2008, while the strongest surge $(140 \%)$ in the number of people was expected in the later stages of the HIV/AIDS lifecycle, namely from about 0,9 million in 2002 to about 2,2 million in 2008 (BMR, 2004).

TABLE 1

HIV-POSITIVE POPULATION BY STAGE, 2002 TO 2008 IN SOUTH AFRICA

\begin{tabular}{lcccc}
\hline Year & Early stages & Middle stages & Later stages & Total \\
\hline 2002 & 1810120 & 2458040 & 931840 & 5200000 \\
2004 & 1659080 & 2815480 & 1425440 & 5900000 \\
2006 & 1795600 & 2955370 & 1949030 & 6700000 \\
2008 & 2123250 & 3142500 & 2234250 & 7500000 \\
\hline
\end{tabular}

Source: BMR, 2004.

Vass (2002) reported that the macro-economic modelling results indicated that, given the impact of HIV/AIDS, labour force growth would decline, resulting in a smaller labour force compared to a one in a no-Aids scenario. Quattek (2000) predicted an $18 \%$ decline in the labour force by 2015 , while Abt/Metropolitan predicted a decline of $21 \%$ by 2015 (BER 2001). The projected reduction in the labour force follows from the projected reduction in the population growth rate to zero per cent in 2009 and a negative growth rate of $-0,5 \%$ by 2015 .

Culture plays a vital role in determining the level of health of the individual, the family and the community. This is particularly relevant in the context of Africa, where the values of extended family and community significantly influence the behaviour of the individual (Airhihenbuwa \& Webster, 2004). The research of Norman and Carr (2003) also indicated that it is clear that culturally appropriate and stage-specific strategies are urgently needed.

TABLE 2

STAGES OF HIV/AIDS USED IN ASSA 2002

\begin{tabular}{ll}
\hline Stage & Description \\
\hline 1 & WHO stage 1: Acute HIV infection \\
2 & WHO stage 2: Early disease \\
3 & WHO stage 3: Late disease \\
4 & WHO stage 4: AIDS \\
5 & Receiving antiretroviral treatment \\
6 & Discontinued antiretroviral treatment \\
\hline
\end{tabular}

Source: Dorrington et al. (2004)

As indicated in Table 2, the ultimate stage of the virus is fullblown AIDS. At this stage, in most cases symptoms such as weight loss and balding start to show. Chronic diarrhoea is also common.

Human Resource Practitioners, more specifically Human Resource managers, have broad responsibilities for managing multiple aspects of their organisation's response the HIV/AIDS epidemic. MacDonald and George (2002) were of the opinion that Human Resource managers ought to have a particularly important role to play in an organisational response to HIV/AIDS. It is these managers' responsibility to manage problems in the workplace caused by HIV/AIDS at both an 
organisational and individual level. These officers are responsible for the formulation and implementation of policies and programmes and for the establishment of rules that ensure that those living with HIV/AIDS are protected from discrimination and provided with the best possible care. At the same time, they have responsibilities to protect the interests of the employer. In most cases these seemingly divergent demands coincide as it is in the best interests of the employer to prolong the productive life of employees living with HIV/AIDS and to minimise the numbers of infected employees through intensive workplace prevention interventions as well as through partnerships with community-based organisations.

Human Resource managers and career practitioners ought to be aware of the basic challenges faced by HIV positive South Africans, according to Maloon, Crous and Crafford (2004). Dickinson (2003 p.46) stated in his research: "Thus, in asking whether managing HIV/AIDS in South African workplaces is just another duty the answer is that a new form of management is required in which the strengths of managerial structures and capacity is combined with the enthusiasm and peer communication strength of bottom-up initiatives. This prevents enormous difficulties as South African companies take up the challenge of HIV/AIDS."

Thus to conclude, the perceptions of the HR Practitioners and Managers on how they perceive their role and responsibility in the management of HIV/AIDS in industry are of utmost importance to industry. If they perceive that the management of HIV/AIDS in industry is an integral part of their role, it can have a positive impact in the fight against HIV/AIDS. However, if they perceive their role as a low-profile one and are rather ignorant towards the management of HIV/AIDS, it will definitely have a negative impact regarding the fight against HIV/AIDS in industry.

\section{RESEARCH APPROACH}

\section{Research design}

A cross-sectional survey design was used to achieve the study objectives (Shaughnessy \& Zechmeister, 1997). It was decided for this research to use a cross-sectional survey design because it was the most appropriate design to use. According to Burns and Grove (1993), cross-sectional designs are appropriate where groups or subjects at different developmental stages are studied simultaneously. The survey technique of data collection gathers information from the target population by means of a questionnaire.

This investigation was done by administering semi-structured questionnaires to $250 \mathrm{HR}$ Practitioners by means of e-mail. A convenience sample of the available HR Practitioners was obtained and a total of $65(\mathrm{~N}=65)$ respondents completed the questionnaires. This represents a response rate of $26 \%$. This response rate corresponds with the research of Lim (2003), who had a response rate of $20 \%$ after a first mailing and $29 \%$ response rate out of 550 questionnaires after a second mailing. Du Plessis (2004) had a 38\% response rate out of 350 questionnaires mailed/e-mailed to HR Practitioners and HIV/AIDS Consultants of operating mines, quarries and mineral plants situated in South Africa.

\section{Participants}

The group of HR Practitioners who participated in the research consisted of HR Directors (3\%), HR Managers (26\%), senior HR Practitioners (32\%), and HR Practitioners (38\%). The biggest group of respondents are from the Metals sector (23\%), followed by the Chemical sector (22\%).

The other respondents represented the following sectors: Mining (16\%), Business Service (9\%), Health (9\%), Education (6\%),
General Government (6\%), Consumer Manufacturing (3\%), Construction (3\%) and Machinery (3\%). The majority of respondents $(60 \%)$ worked in the Gauteng province with the remaining provinces proving relatively equal representation in terms of the final sample. The group of respondents consisted of $66 \%$ males and $34 \%$ females.

\section{Measuring instruments}

For the purpose of this research a semi-structured questionnaire was developed by the researcher. Apart from the questionnaire, a biographical questionnaire (part A) was also distributed. The questionnaire consisted of three sub-scales, namely part B (responsibility regarding HIV/AIDS in the workplace), part C (HIV/AIDS) and part D (HIV/AIDS-perceptions. Because the topic being studied is sensitive it was essential to assure respondents of anonymity and confidentiality. The questions posed, were closed-ended questions based on a 3-point revised Likert scale (Agree, Unsure and Disagree).

This is a newly designed questionnaire. No data is available regarding the validity and reliability of the measuring instrument.

\section{Statistical analysis}

The statistical analysis was carried out with the aid of the SPSS program (SPSS, 2003) and SAS program (SAS Institute, 2000.)

\section{RESULTS}

A biographical questionnaire was developed to gather information about the demographic characteristics of the participants. Information that was gathered included the following: position of $\mathrm{HR}$ Practitioner, sector in which the company operates, province the company is situated, number of employees, male/female, skills-levels, labour turnover and absenteeism rate.

The respondents indicated that the biggest group (28\%) represents companies who employ between 1 000-4 999 employees, 26\% with more than 5000 employees and $17 \%$ who employ between 100-499 employees. The rest (17\%) represent companies who employ less than 100 employees. The respondents reported that the biggest portions of their employees (57\%) are semi-/unskilled, 24\% skilled and 19\% highly skilled. The respondents reported their latest \% labour turnover as: semi-/unskilled $(2,8 \%)$, skilled $(1,5 \%)$ and highly skilled $(0,1 \%)$. They reported their latest absenteeism rate $\%$ as: semi-/unskilled (6\%), skilled (2\%) and highly skilled $(0,2 \%)$.

Confirmatory factor analyses were carried out to determine the construct validity of Section D: HIV/AIDS Perceptions. Section D consists of two scales, the first relating to perceptions regarding the impact of HIV-infected persons at the workplace, and the second section relating to perceptions regarding access to information regarding employees' HIV status. A simple principal components analysis was done to verify the construct validity of Section D. Two factors emerged, which together explained 39\% of the total variance.

\section{TABLE 3}

DESCRIPTIVE STATISTICS AND CRONBACH'S ALPHA COEFFICIENTS, SKEWNESS AND KURTOSIS OF THE MEASURING INSTRUMENT

\begin{tabular}{lccccccc}
\hline Test and subscales & $\mathrm{N}$ & Mean & Minimum & SD & Skewness & Kurtosis & $\alpha$ \\
\hline Perceptions Q42 & 65 & 22,01 & 14,00 & 5,40 & 0,657 & 0,102 & 0,82 \\
Perceptions Q43 & 65 & 10,68 & 6,00 & 3,34 & 0,663 & $-0,02$ & 0,71 \\
\hline
\end{tabular}


As indicated by Table 3, these two subscales demonstrated an adequate level of internal consistency, the first with a Cronbach alpha of 0,82 and the second falling at 0,71 . These compare favourably with the guideline of 0,70 as set by Nunnally and Bernstein (1994). According to Hair et.al (1998), Cronbach's alpha value may be decreased to 0,6 in exploratory research. It can therefore be concluded that all factors are internally reliable.

\section{Responsibility regarding HIV/AIDS}

The themes which addressed this part of the questionnaire identified whose responsibility HIV/AIDS is in the workplace, and social responsibility involvement towards the community and the employees.

The respondents singled out Human Resources (28\%) to be responsible for HIV/AIDS in the workplace, compared to 5\% who designated top-management. The majority of the respondents (62\%) reported that all the role-players (Human Resources, topmanagement, line-management and the trade unions) should all be responsible for the management of HIV/AIDS in the workplace.

The majority of the respondents (56\%) singled out community involvement as the biggest priority regarding social involvement of the companies. About two-thirds of the respondents (62\%) reported that their company policy provides for the principle of being socially responsible towards the community and the employees. The rest of the respondents (38\%) reported that their company policy makes provision of being socially responsible towards the communities and the employees "to some extent". About half of the respondents (48\%) indicated a "definitely yes" regarding the question: "Do you believe that your company fulfils its task towards social responsibility?" Half of the respondents (50\%) reported "to some extent" and the minority of the respondents $(2 \%)$ reported "not at all". About one-fifth of the respondents (23\%) indicated that their companies spend less than $1 \%$ of their companies' gross income towards social responsibility.

One-third of the respondents (34\%) indicated that their companies spend between $1 \%-2 \%$ of their gross income towards social responsibility, while $20 \%$ reported expenditure of between $2 \%-3 \%, 15 \%$ between $3 \%-4 \%$ and $8 \%$ between 4\%-5\%.

The majority of the respondents (84\%) are of the opinion that, to be socially responsible, can improve their company's image internationally and nationally. The element that was singled out as the most important element regarding social responsibility towards employees $(60 \%)$ was "education of employees". The element that was singled out as the least important element (34\%) towards social responsibility was "employment of disabled employees". There were mixed responses regarding the least important elements of social responsibility, namely: improvement of living standards $(8 \%)$, medical/pension $(11 \%)$, housing $(13 \%)$, sport and recreation $(16 \%)$ and transport for employees (16\%). The element that was singled out as the most important element regarding social responsibility towards the community was "employment" (48\%) while "sponsorships" (33\%) was singled out to be the least important element.

\section{HIV/AIDS}

The themes which addressed this part of the questionnaire focused on: HIV/AIDS policy issues, HIV/AIDS programmes, the effect of HIV/AIDS on production, HIV/AIDS-related costs, HIV/AIDS-training, HIV-testing, counselling etc.

The majority of the respondents (91\%) reported that their company have a HIV/AIDS policy in place. A small portion
$(6 \%)$, were unsure and a few (3\%) reported that their company did not have a HIV/AIDS policy in place. About one-third of the respondents (37\%) indicated that their company's HIV/AIDS policy has been in place for more than 4 years, while about half (45\%) indicated a period of between 1-3 years, $15 \%$ indicated less than 1 year, while $3 \%$ indicated "not yet in place"

The biggest portion of respondents (89\%) reported an HIV/AIDS awareness programme, about three-quarters (76\%) reported a voluntary counselling and testing programme, and more than two-thirds $(70 \%)$ reported a HIV/AIDS care, support and treatment programme. About half of the respondents (54\%) indicated that their companies do not make provision for antiretroviral therapy at the workplace. The majority of the respondents $(58 \%)$ indicated that HIV/AIDS prevention programmes will have a small to moderate increase on the labour costs of their companies. Only about half of the respondents (48\%) reported that their companies conducted research to assess the impact of HIV/AIDS on the labour force, production costs and consumer base.

TABLE 4

RESULTS REGARDING THE RESPONDENTS' VIEWS REGARDING THE EFFECT OF HIV/AIDS ON THE PRODUCTION SIDE OF THEIR COMPANIES

\begin{tabular}{|c|c|c|c|c|c|c|}
\hline \multicolumn{2}{|r|}{ No HIV/AIDS has led to: } & \multirow{2}{*}{$\begin{array}{c}\begin{array}{c}\text { No } \\
\text { impact } \\
\%\end{array} \\
31\end{array}$} & \multirow{2}{*}{$\begin{array}{c}\begin{array}{c}\text { Small } \\
\text { impact } \\
\%\end{array} \\
27\end{array}$} & \multirow{2}{*}{$\begin{array}{c}\begin{array}{c}\text { Moderate } \\
\text { impact } \\
\%\end{array} \\
27\end{array}$} & \multirow{2}{*}{$\begin{array}{c}\begin{array}{c}\text { Large } \\
\text { impact } \\
\%\end{array} \\
2\end{array}$} & \multirow{2}{*}{$\begin{array}{c}\begin{array}{c}\text { Don't } \\
\text { know } \\
\%\end{array} \\
13\end{array}$} \\
\hline 1 & Lower labour productivity & & & & & \\
\hline 2 & Increased worker absenteeism & 12 & 47 & 22 & 8 & 11 \\
\hline 3 & Higher labour turnover rates & 31 & 24 & 22 & 8 & 15 \\
\hline 4 & $\begin{array}{l}\text { Lost of experience and } \\
\text { vital skills }\end{array}$ & 37 & 24 & 14 & 10 & 15 \\
\hline 5 & $\begin{array}{l}\text { Higher recruitment/ } \\
\text { training costs }\end{array}$ & 28 & 30 & 15 & 12 & 15 \\
\hline 6 & $\begin{array}{l}\text { Higher employee benefit } \\
\text { costs }\end{array}$ & 27 & 33 & 20 & 8 & 12 \\
\hline
\end{tabular}

Table 4 summarises the percentages of respondents' perceptions regarding the effect of HIV/AIDS on the production side of their companies. As indicated in Table 4, more than half of the respondents (58\%) indicated that HIV/AIDS will have no/small impact towards lower labour productivity. More than half of the respondents (61\%) indicated that HIV/AIDS will have no/small impact towards a loss of experience and vital skills.

Only a few respondents indicated a large impact on: lowered labour productivity $(2 \%)$, increased worker absenteeism $(8 \%)$, larger labour turnover rates, loss of experience and vital skills $(10 \%)$, higher recruitment and training costs and higher employee benefit costs (8\%).

The majority of the respondents (72\%) reported that their company's HIV/AIDS policy has been communicated to the employees. The rest of the respondents (14\%) reported "no", and the balance (14\%) reported "not sure". More than half of the respondents (59\%) that the right of the employee with HIV/AIDS to privacy is more important than the right of the co-workers (41\%) to know about potential health hazards.

Regarding the aspect of testing, the majority of the respondents (95\%) reported that employees volunteered for testing. Only a few of the respondents (3\%) indicated that testing is mandatory for all employees and the balance of the respondents (2\%) indicated that testing is mandatory for employees in high-risk groups. More than two-thirds of the respondents (68\%) reported that informed consent should be obtained from the employees before any HIV-testing is carried out. Only one-quarter of the 
respondents $(24 \%)$ indicated that the costs, of voluntary or mandatory testing were covered in full by their company's medical aid scheme. A small portion of the respondents (8\%) reported being "partially covered", a few (9\%) reported that their company did not have a medical scheme, and the balance (29\%) indicated "not covered".

Awareness posters were reported as the most common method (93\%) of communication regarding HIV/AIDS awareness/ education, while use of industrial theatre was less common $(48 \%)$. The majority of the respondents $(60 \%)$ indicated that their union/unions had taken a position similar to their own regarding the management of HIV/AIDS.

More than half of the respondents (54\%) reported that they used the Labour Relations Act (Code of Good Practice) as a basis for drawing up their AIDS policy/education campaign. About half of the respondents (42\%) indicated that HIV/AIDS has had a significant adverse impact on their company (for example production, sales and profits).

\section{HIV/AIDS perceptions}

The themes which addressed this part of the questionnaire focused on respondents' perceptions regarding the effect HIV/ AIDS would have on the workplace within the working context.

\section{TABLE 5}

RESUlTS REgaRding THE RESPONDENTS' PERCEPTIONS OF HIVINFECTED PERSONS IN THE WORKPLACE

\begin{tabular}{|c|c|c|c|c|c|}
\hline No. & $\begin{array}{l}\text { I believe that allowing HIV- } \\
\text { infected persons to work at the } \\
\text { workplace will: }\end{array}$ & $\begin{array}{l}\text { Agree } \\
\%\end{array}$ & $\begin{array}{l}\text { Disagree } \\
\%\end{array}$ & $\begin{array}{l}\text { Unsure } \\
\%\end{array}$ & $\begin{array}{c}\text { Total } \\
\%\end{array}$ \\
\hline 1 & $\begin{array}{l}\text { Cause some employees to refuse job } \\
\text { assignments. }\end{array}$ & 62 & 22 & 16 & 100 \\
\hline 2 & Undermine company morale. & 78 & 20 & 2 & 100 \\
\hline 3 & Result in lost sales. & 74 & 18 & 8 & 100 \\
\hline 4 & Hurt the company image. & 90 & 8 & 2 & 100 \\
\hline 5 & Result in acts of violence. & 86 & 9 & 5 & 100 \\
\hline 6 & Increase our medical insurance costs. & 32 & 15 & 53 & 100 \\
\hline 7 & Cause us to lose our customers. & 78 & 17 & 5 & 100 \\
\hline 8 & $\begin{array}{l}\text { Increase the number of grievances } \\
\text { and complaints. }\end{array}$ & 59 & 26 & 15 & 100 \\
\hline 9 & $\begin{array}{l}\text { Diminish the ability of other } \\
\text { employees to concentrate on } \\
\text { their work. }\end{array}$ & 63 & 23 & 14 & 100 \\
\hline 10 & Increase labour costs & 23 & 23 & 54 & 100 \\
\hline 11 & Disrupt the flow of work & 49 & 17 & 34 & 100 \\
\hline 12 & Cause some employees to quit. & 59 & 25 & 16 & 100 \\
\hline 13 & $\begin{array}{l}\text { Undermine our ability to provide } \\
\text { service to clients }\end{array}$ & 65 & 18 & 17 & 100 \\
\hline 14 & $\begin{array}{l}\text { Incur extra expenditure in hiring } \\
\text { additional labour to buffer against } \\
\text { any work disruption. }\end{array}$ & 34 & 26 & 40 & 100 \\
\hline
\end{tabular}

Table 5 summarised the percentages of respondents indicating their perceptions of HIV-infected persons in the workplace. More than two-thirds (62\%) of the 65 respondents indicated their agreement with statement 1 indicating that presence of HIV-infected persons would cause some employees to refuse job assignments. The majority (78\%) of the respondents agreed with statement 2 indicating that the presence of HIV-infected persons in the workplace would undermine company morale. This corresponds with the results of statement 3 , where $74 \%$ of the respondents agreed with the statement that the presence of HIVinfected persons in the workplace would result in lost sales to their company.

Most (90\%) of the respondents agreed with statement 4 indicating that HIV-infected employees would hurt the company image and the majority (86\%) of the respondents felt that HIV- infected persons at the workplace could result in acts of violence (statement 5). About half (53\%) of the respondents were unsure about statement 6 indicating that accommodation of HIVinfected employees could lead to an increase in the medical insurance costs of the company. One-third (32\%) of the respondents agreed with this statement while $15 \%$ disagreed. The majority (78\%) of the respondents felt that HIV-infected employees can cause that the company loses some customers (statement 7).

More than half $(59 \%)$ of the respondents were of the opinion that the number of grievances and complaints would increase (statement 8) and about the same number (63\%) feel that it will diminish the ability of other employees to concentrate on their work (statement 9).

More than half (54\%) of the respondents were uncertain about the contents of statement 10 that HIV-infected employees could result in an increase in labour costs. About half (49\%) of the respondents agreed with statement 11 that participation of HIV-infected persons at the workplace would disrupt the flow of work. More than half $(59 \%)$ of the respondents agreed with statement 12 that the use of HIV-infected employees could cause some employees to quit their jobs. About two-thirds (65\%) of the respondents agreed with the statement that job involvement of HIV-infected employees would undermine the ability of the company to provide service to clients. There were mixed results regarding statement 14 that HIV-infected persons would lead to increased expenditure due to hiring of additional labour to buffer work disruptions.

TABLE 6

RESULTS REgARDING THE RESPONDENTS' PERCEPTIONS OF HIVINFECTED PERSONS IN THE WORKPLACE

\begin{tabular}{|c|c|c|c|c|c|}
\hline No. & In context of the workplace & $\begin{array}{c}\text { Agree } \\
\%\end{array}$ & $\begin{array}{c}\text { Disagree } \\
\%\end{array}$ & $\begin{array}{c}\text { Unsure } \\
\%\end{array}$ & $\begin{array}{c}\text { Total } \\
\%\end{array}$ \\
\hline 1 & $\begin{array}{l}\text { Employers should have access to } \\
\text { information about the outcome of } \\
\text { employees' AIDS tests without } \\
\text { knowing the identities of these } \\
\text { candidates. }\end{array}$ & 30 & 4 & 66 & 100 \\
\hline 2 & $\begin{array}{l}\text { Potential employers should have } \\
\text { access to information about the } \\
\text { outcome of employees' AIDS tests, } \\
\text { without knowing the identities of } \\
\text { these test candidates. }\end{array}$ & 49 & 13 & 38 & 100 \\
\hline 3 & $\begin{array}{l}\text { Workers who work around HIV- } \\
\text { infected employees should have } \\
\text { access to information about the } \\
\text { outcome of employees' AIDS tests, } \\
\text { without knowing the identities of } \\
\text { these test candidates. }\end{array}$ & 40 & 18 & 42 & 100 \\
\hline 4 & $\begin{array}{l}\text { Employers should have access to } \\
\text { information about the identities of } \\
\text { employees who have AIDS tests. }\end{array}$ & 71 & 5 & 24 & 100 \\
\hline 5 & $\begin{array}{l}\text { Potential employers should have } \\
\text { access to information about the } \\
\text { identities of employees who have } \\
\text { had AIDS tests. }\end{array}$ & 67 & 9 & 24 & 100 \\
\hline 6 & $\begin{array}{l}\text { Workers who work around HIV- } \\
\text { infected employees should have } \\
\text { access to information about the } \\
\text { identities of employees who have } \\
\text { had AIDS tests. }\end{array}$ & 75 & 10 & 15 & 100 \\
\hline
\end{tabular}

The results of the respondents regarding their perceived attitudes towards HIV-infected persons in the workplace (with specific reference to access to information about the outcome of employees' AIDS tests as well as the identities of employees who have had AIDS tests) were summarised in Table 6.

Two-thirds $(66 \%)$ of the respondents reported that they were uncertain if employers should have access to information about the outcome of employees' AIDS tests without knowing the 
identities of these candidates (statement 1). About half (49\%) of the respondents agreed with statement 2 that potential employers ought to have access to information about the outcome of employees' AIDS tests. This corresponded with the results of statement 3 where $40 \%$ of the respondents agreed that workers who work in proximity to HIV-infected employees should have access to information about the outcome of employees' AIDS tests, while $42 \%$ of the respondents were unsure.

The majority (71\%) of the respondents felt that employers, potential employers and workers should have access to information about the identities of employees who have had AIDS tests. The minority (8\%) of the respondents disagreed, while $21 \%$ of the respondents were unsure.

\section{DISCUSSION}

The objectives of this study were to analyse the perceptions of HR Practitioners regarding their role and responsibility in the management of HIV/AIDS in industry.

An in-depth discussion of the results of the descriptive statistics of the individual variables fell beyond the scope of this research. A few remarks, however, were made regarding those factors with significant statistics. The following section dealt with the descriptive statistics of Sections B, C and D of the questionnaire.

From Table 4, it was clear, that the respondents were of the opinion that HIV/AIDS has had a limited or moderate impact on lower labour productivity, increased worker absenteeism and higher labour turnover rates. Furthermore, it was evident, that companies experienced a slight or moderate impact on increasing of higher employee benefit costs. In contrast to this "moderate" view, Du Plessis (2004, p. 289) reported: "Less visible though, is the alarming impact HIV/AIDS is currently having on a company's bottom line." This stems from costs arising from lowered productivity due to those employees who prematurely died of the disease or before retirement age having to be replaced and this led to additional recruitment, training and vesting costs that incurred with regard to the replacement of employees.

From Table 5, it became evident, that on average $61 \%$ of the respondents agreed with the 14 negatively defined statements that HIV/AIDS would have a negative impact on the company. Some of the major concerns were that HIV-infected persons at the workplace would hurt the company image (90\%), result in acts of violence $(86 \%)$, undermine company morale (78\%) and cause the company to lose customers (78\%).

Table 6 focused on the perceived attitudes of the respondents regarding their views on HIV-infected persons at the workplace. The results of Table 6 on average indicated agreement $(55 \%)$ that employers, potential employers and workers who worked closely with HIV-infected people ought to have access to information about the identities of employees who have had HIV tests. Ten percent of the respondents disagreed (10\%) with the statement and indicated "unsure" on average (35\%) regarding the six elements of Table 6 .

This research was administered only to the 250 respondents who mainly resident in Gauteng, Free State and North West province. Therefore, one could argue that the findings are not necessarily a generalisation of all HR Practitioners' perceptions and views in all the economic sectors of South African regarding their role and responsibility in the management of HIV/AIDS. It does, however, serve as a point of reference for future research on this topic. One of the limitations of this research was that the questionnaire used was a self-report questionnaire. Furthermore, the study was cross-sectional whereas the results of a longitudinal study might have been more useful. Another limitation of this research was that it was only administered to respondents who have access to computer network and e-mail facilities.

\section{RECOMMENDATIONS}

Based on the results of this study, the following recommendations were proposed for future research in the area of HIV/AIDS with specific reference to the role of HR Practitioners in the management of HIV/AIDS.

- A fundamental responsibility of the HR Practitioner is to develop a human resources plan for his or her organisation. Any such plan must consider the possible impact of HIV/AIDS on the organisation in the short, medium and long term.

- An AIDS preventative programme should be developed and implemented at all plants of a company to promote changes in lifestyle and to prevent the spread of HIV/AIDS.

- Awareness programmes can help in creating awareness and understanding of the disease; to address negative attitudes and misconceptions about HIV/AIDS.

- Awareness programmes should aim to change the social climate at the workplace and at home to support preventative behaviour. Existing customs and traditions of workers should be considered when developing these programmes.

- There should be sufficient training on how to deal with HIVinfected workers and colleagues for co-workers at all levels in the organisation.

\section{RECOMMENDATIONS FOR FUTURE RESEARCH}

A major challenge for organisations in the future seems to be an urgent search for competitive advantage. In the South African context, this is an even a bigger challenge for companies facing the growing impact of HIV/AIDS at the workplace. Companies that do attend to and manage HIV/AIDS in their workplace will have a decided advantage in this regard.

In the light of the fact that limited research in the area of HIV/AIDS (with specific reference to the role of HR Practitioners) had been done, further studies might on a wider scale be undertaken in order to generate a better and more general view of the attitudes, perceptions and awareness among HR Practitioners of AIDS and AIDS-related issues in the work context. Research on knowledge of HIV/AIDS and the practices of unprotected sex tends to be cross-sectional. Future research needs to focus on longitudinal studies regarding the management of HIV/AIDS in the workplace.

Managers involved in the "softer sciences" like Human Resources Practitioners should receive some training to have a better understanding of the economic impact of HIV/AIDS on their companies. HIV/AIDS has become a major threat to employment objectives on labour market efficiency. More research regarding the economic impact of HIV/AIDS in companies is needed.

\section{REFERENCES}

Abt Associates Inc. (2000). Demographic Impact of HIV/Aids in South Africa. Sandton: Abt Associates Inc.

Airhihenbuwa, C.O, \& Webster, J.de W. (2004). Culture and African contexts of HIV/AIDS prevention, care and support. Journal of Social Aspects of HIV/AIDS 1 (1), 4 -13.

BER, see Bureau for Economic Research.

BMR, see Bureau of Market Research

Bureau for Economic Research. (2001). The Macro-economic impact of HIV/AIDS in South Africa. Research Note No 10. BEO Stellenbosch: University of Stellenbosch. 
Bureau for Economic Research. (2006). The macro-economic impact of HIV/AIDS under alternative intervention scenarios (with specific reference to ART) on the South African economy. BER Stellenbosch: University of Stellenbosch.

Bureau of Market Research. (2004). The projected economic impact of HIV/AIDS in South Africa, 2003-2015. Pretoria: Unisa, Bureau of Market Research (Report no 325)

Caldwell, J.C. (2000). Rethinking the African AIDS epidemic. Population and Development Review, 26 (1), 117-135.

Cameron, E. (2005). Witness to AIDS. Cape Town: Tafelberg.

Department of Health, South Africa (2005). National HIV and syphilis antenatal sero-prevalence survey in South Africa 2004. Department of Health. Pretoria.

De Vos, A.S. (Ed.), Strydom, H, Fouché, C.B, Delport, C.S.L. (2002). Research at Grass Roots. For the social sciences and human service professions. Pretoria: Van Schaik.

Dickinson, D. (2003). Managing HIV/AIDS in the South African workplace: just another duty? South African Journal of Economic and Management Sciences, 6 (1),25-49.

Dickinson, D. (2004). Corporate South Africa's response to HIV/AIDS: why so slow? Journal of South African Studies, 30 (3),627-649.

Dorrington, D. (2002). The demographic impact of HIV/AIDS in South Africa by province, race and class. Cape Town: Centre for Actuarial Research, University of Cape Town.

Dorrington, R.E, Bradshaw, D, Johnson, L \& Budlender, D. (2004). The Demographic impact of HIV/AIDS in South Africa. National indicators for 2004. Cape Town: Centre for Actuarial Research, South African Medical Research Council and Actuarial Society of South Africa.

Du Plessis, W. (2004). The social responsibility of the South African Mining Companies dealing with HIV/AIDS. Potchefstroom: North-West University. Thesis (PhD).

Firmansyah, S, \& Kleiner, B.H. (1999). New developments concerning discrimination against workers with HIV or AIDS. Equal Opportunities International 18 (2/3/4),56 -59)

Garbus, L. 1998. HIV insite: South Africa. http://hivinsite.ucsf

International Labour Organisation. (2000). Action against HIV/Aids in Africa: An initiative in the context of the world of work. Geneva.

Govender, K.K. (2000). Managing service quality: Human Resources management strategies. Journal of Industrial Psychology, 26 (3), 47-51.

Hair, J.F, Anderson, R.E, Tatham, R.L. \& Black, W.C. (1998). Multivariate data analysis. New Jersey: Prentice Hall Inc.

Heider, F. (1944). Social Perception and Phenomenal Causality. Psychological Review, 51, 358-374.

Jones, E.E., \& Davis, K.E. (1965). From Acts to Dispositions: The Attribution Process in Person Perception. In L. Berkowitz (ed.), Advances in Experimental Social Psychology (2). New York: Academic Press. Inc.

Kaiser Family Foundation. (2000). Impending catastrophe revisited: an update on the HIV/Aids epidemic in South Africa. Abt Associates Inc.

Kelly, H. (1967). Attribution Theory in Social Psychology. In D. Levine (ed.), Nebraska Symposium on Motivation. Lincoln NB: University of Nebraska Press.

Kinghorn, A. \& Steinberg, M. (2000). HIV/AIDS in South Africa: the impact and priorities. R.S.A.
Lee, G.J, Venter, R. \& Bates, B. (2004. Enterprise-based HIV/AIDS strategies: Integration through organizational architecture. South African Journal of Business Management, 35 (3), 13-22.

Lim, V.K.G \& Loo, G.K. (2000). HIV and the workplace: Organisational consequences of hiring persons with HIV and attitudes towards disclosure of HIV-related information. International Journal of Manpower, 21 (2), 129-140.

Lim, V.K.G. (2003). Managing HIV at the workplace: an empirical study of HIV and HR Managers in Singapore. Journal of Occupational Health Psychology, 8 (4), 235-246.

MacDonald, J \& George, G. (2002). Human Resource Managers. AIDS Brief for Professionals. Health Economics and HIV/AIDS Research Division, University of Natal, Durban. October: 1-6.

Maloon, D., Crous, F. \& Crafford, A. (2004). Work-related concerns of South Africans living with HIV and AIDS. South African Journal of Industrial Psychology, 30 (2),96-150.

Marais, H. (2000). To the edge: AIDS review 2000. Centre for the study of AIDS: University of Pretoria.

Neuman, W.L. (1997). Social Research Methods: Qualitative and Quantitative Approaches. Boston: Allyn and Bacon.

Norman, L.R. \& Carr, R. (2003). The role of HIV knowledge on HIV-related behaviours: a hierarchical analysis of adults in Trinidad. Health Education, 103 (3), 145-155.

Nunnally, J.C., \& Bernstein, I.H. (1994). Psychometric theory (3rd ed.). New York: McGraw-Hill.

Quattek, K. (2000). The economic impact of Aids on South Africa: a dark cloud on the horizon. Johannesburg: ING Barings.

SAS Institute. (2000). The SAS System for Windows: Release 8.01. Cary, NC: SAS Institute Inc.

Shaugnessy, J.J \& Zechmeister, E.B. (1997). Research methods in psychology (4th ed.) New York: McGraw-Hill.

Smith, J.J \& Krüger, J. (2005). Perceptions of graduates regarding workplace expectations: An exploratory study. South African Journal of Business Management, 36 (1), 23-31.

SPSS Inc. (2003). SPSS 12.0 for Windows. Chicago, IL: Author.

Statistics South Africa. (2004). Mid-year population estimates, South Africa 2004. Pretoria.

Stats SA, see Statistics South Africa.

Sunter, C. \& Whiteside, A. (2000). AIDS: the challenge for South Africa. Cape Town: Human E Rousseau.

UNaids \& WHO. (2005). Aids epidemic update: December 2005. Switzerland.

Van Aardt, C. (1999, October 5-11). The impact of new demographic trends on the labour market. Paper presented at the 1999 DEMSA Conference, Cape Town (5-11 October).

Van Wyk, C. de W, \& Tshivase, N.D. (2005). HIV/AIDS awareness and attitudes of mineworkers: A case study. South African Journal of Business Management, 36 (1), 65-72.

Van Wyk, C de W. (2005, 30 June - 3 July). HIV/AIDS perceptions, attitudes and awareness of undergraduate students. Paper presented at the Fifth International Conference on Diversity in Organisations, Communities and Nations. The Institute of Ethnic Administrators, Beijing, China.

Vass, J. (2002). The relationship between labour market dynamics and HIV/Aids prevalence: A literature review. Development Policy Research Unit School of Economics, University of Cape Town.

Wikipedia. Retrieved 15 August, 2006, from, http://www. answers.com/topic/perception/ 